\title{
下フランジにエネルギー吸収要素を設置した梁継手 BEHAVIOR OF BEAM SPLICES WITH ENERGY DISSIPATING ELEMENTS AT THE BOTTOM FLANGE
}

\author{
吉敷祥 - *1, 上原大輔*2，山田哲*3 \\ 鈴木一 弁*4, 佐伯 英一郎*5, 和 田 章*6 \\ Shoichi KISHIKI, Daisuke UEHARA, Satoshi YAMADA, \\ Kazuaki SUZUKI, Eiichiro SAEKI and Akira WADA
}

\begin{abstract}
A new type of seismic beam-end splice is proposed which uses a hysteretic damper as the splice element at the bottom flange of the beam. The design intent of this beam-end splice is to concentrate plastic deformation of the beam to a replaceable damper-and-splice element while limiting damage to the concrete slab. Non-degrading hysteretic characteristics of the damper-and-splice element is achieved by adequate buckling restraints. Based on axial loading tests of the damper-and-splice element and simple mechanics, design equation for the buckling restraints were established. Beam-column subassemblages implementing the proposed beam-end splice exhibited excellent cyclic loading behavior. Concerns regarding web crippling of the beam directly below the top flange splice are addressed.
\end{abstract}

Keywords : beam splice, buckling restraining, web crippling, hysteretic damper, damage-controlled-structure 梁継手, 座屈補剛, ウェブクリップリング, 履歴型ダンパー, 損傷制御構造

1. 序

地震時の人命保護のみならず，財産・機能保持を目的とした 損傷制御構造 ${ }^{1}$ が高層建物を中心に広く普及している。 また，従 来のブレース型ダンパーなどが設置し難い中低層建物において も方杖状にダンパーを設置したり ${ }^{2)}$.3)，梁下フランジの一部にダ ンパーを設置した構造システム4) 10)なとが提案されている(後者を 総称して梁下ダンパー)．梁下ダンパーを用いると主架構の梁端 部で高い補修性が確保できるため, 従来のダンパーと併用する ことでさらに設計の自由度が広がる。しかしながら，これまで の梁下ダンパーはスプリットティ ${ }^{10)}$ やアングルなど(6) 9)を用いて 引張接合部されているほか， $\mathrm{H}$ 形鋼弱軸柱に水平スチフナを利 用して接合されている4)，5)ため，梁下ダンパーを適用できる柱形 式や建物の規模は限られる。ここでは梁下ダンパーを強軸・弱 軸の方向性のない「角形鋼管柱に通しダイアフラム形式で梁を 溶接接合する一般的な柱梁接合部」一適用するため, 梁継手部 分の下フランジに座屈補剛を施した塑性化スプライスを設置す る構造システムを考える(図 1.). 本研究では継手部分に塑性化 スプライスを設置した梁の繰り返し曲げせん断実験を行い, 塑 性化スプライスを用いた際の力学挙動や構造的特徽を明らかに

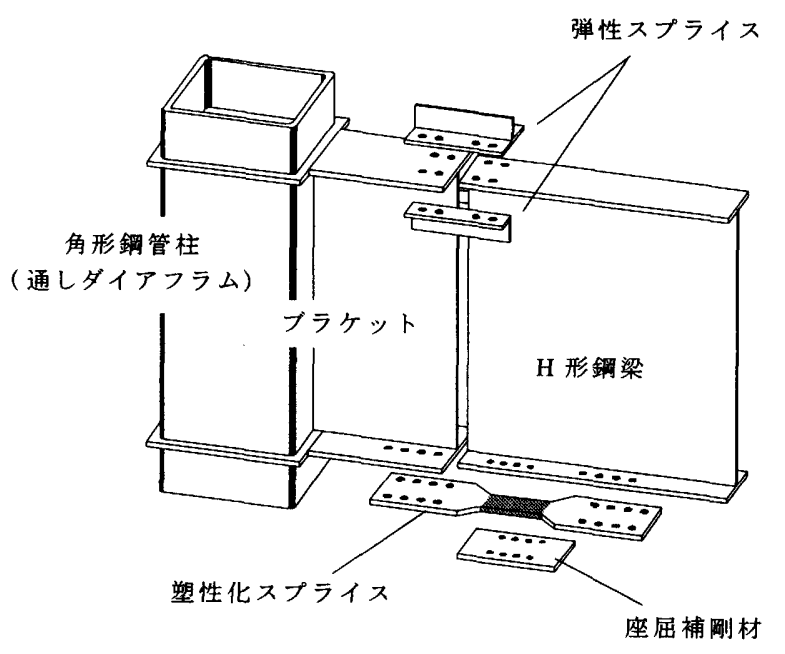

図1. 塑性化スプライスを用いた梁継手

する.また、これに先立って塑性化スプリットティの実験 10 )，11) では曖昧であった塑性化部におけるクリアランスの確保方法を 新たに提示し，塑性化スプライスのみを取り出した要素実験か ら座屈補剛条件の違いが履歴挙動に及ぼす影響を考察する。

\footnotetext{
*1 日本学術振興会特別研究員 - 修士 (工学) (東京工業大学大学院 博士後期課程)

*2 元 東京工業大学大学院 修士課程・修士 (工学)

*3 東京工業大学建築物理研究センタ一 助教授・博士 (工学)

*4 新日本製鐵建築事業部 マネージャー・修士(工学)

*5 新日本製鐵建築事業部 部長・博士 (工学)

*6 東京工業大学建築物理研究センター 教授・工博
}

JSPS Research Fellow, M. Eng.

(Graduate Student, Tokyo Institute of Technology)

Former Graduate Student, Tokyo Institute of Technology, M. Eng. Assoc. Prof., S.E.R.C., Tokyo Institute of Technology, Dr. Eng.

Building Construction Division, Nippon Steel Corporation, M. Eng. Building Construction Division, Nippon Steel Corporation, Dr. Eng. Prof., S.E.R.C., Tokyo Institute of Technology, Dr. Eng. 


\section{2.塑性化スプライス要素の軸方向繰り返し載荷実験}

\section{1. 実験概要}

\subsection{1. 座屆補剛方法と実験目的}

塑性化スプライスの座屈補剛は, 図 2.に示すように座屈補剛 材と梁下フランジで塑性化部を挟み込むことで行う。塑性化ス プリットティでは塑性化部におけるクリアランスの確保が暧昧 であった ${ }^{10)}$ １11が，本研究では座屈補剛材を「塑性化部の公称板 擪十クリアランス」の高さを持たせたリングを介して取り付け， リングにより確保されたクリアランスで塑性化部のポアソン効 果による断面積増大を吸収する。座屈補剛材を設置した状態で の塑性化部断面を図 3.に示す。断面図からも明らかなように座 屈補剛材を取り付ける高力ボル卜は面内方向への座屈補剛を兼 ねている. 本研究ではまず，この明確なクリアランス確保方法 を適用した塑性化スプライスの塑性化部分のみを取り出し, 軸 方向絽り返し載荷実験を行い，座屈補剛条件が塑性化スプライ スの履歴挙動に及ぼす影響を考察する。

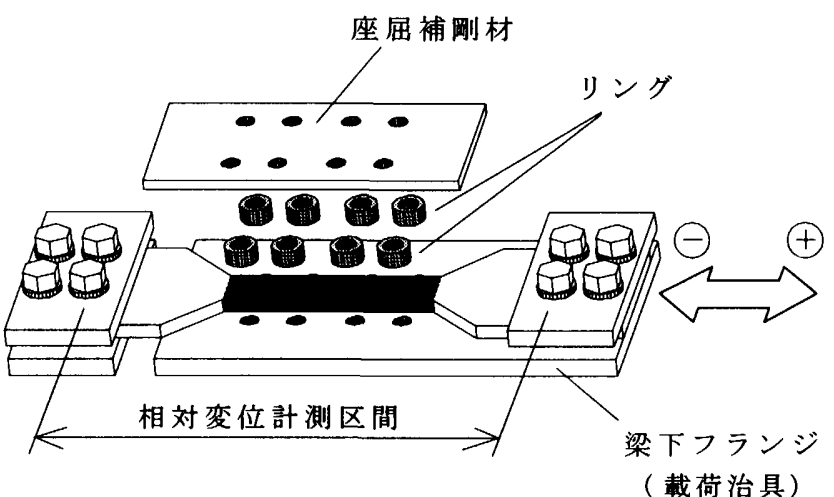

図2. 座屈補剛方法

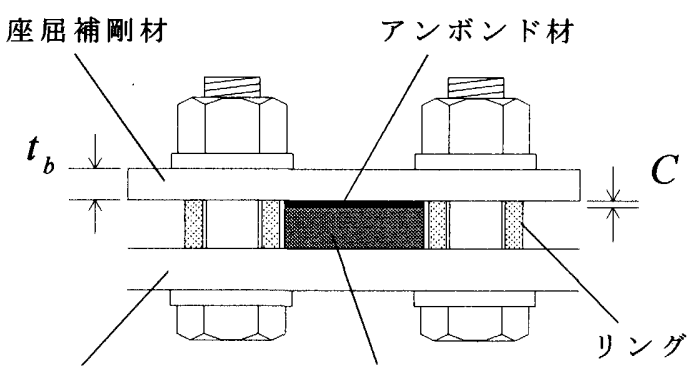

梁下フランジ

塑性化部

図 3. 座屈補剛材を設置した状態（断面図）
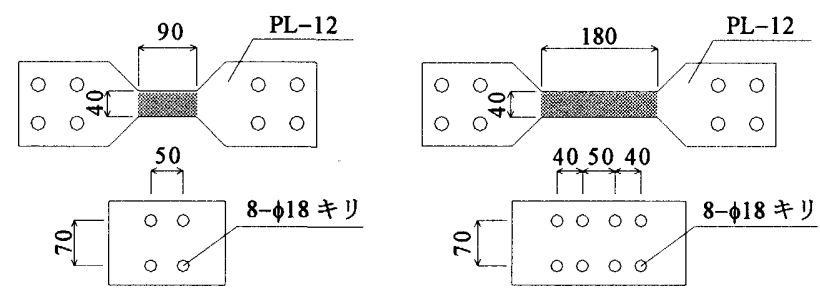
(a) S シリーズ
(b) L シリーズ

図 4。試験体詳細

\subsection{1. 試験体}

試験体は図 4. に示すように塑性化部，載荷装置との接合部，お よび座屈補剛材から構成される。接合部から塑性化部への絞り 込み角度は $45^{\circ}$ とし，コーナー部は $\mathrm{R}=0.5$ で仕上げた．次章で行 う部材実験（梁断面：BH-450x130x6x9）に設置することを想定し て試験体の塑性化部は梁フランジ原断面の約 $40 \%$ に相当する $12 \times 40$ とし，低降伏点銅（LYP225）により製作した。使用した低降 伏点銅の JIS-1A 号引張試験片による素材試験結果を表 1. に示す.

試験体は塑性化部の長さによって S シリーズと L シリーズに大 別される. 各シリーズごとに図3.に示す面外クリアランス $(: C)$ ， 座屈補剛材の板厚 $\left(: t_{b}\right)$ を実験パラメータとし, 表 2 . に示寸計 12 体の試験体を用意した．塑性化部の長さは梁継手の回転変形で $1 / 100 \mathrm{rad}$. に相当する軸変形 $(4.5 \mathrm{~mm})$ に対し，塑性化部のひずみが $\mathrm{S}$ シリーズでは $5.0 \%, \mathrm{~L}$ シリーズでは $2.5 \%$ となるように設計し た. 塑性化部と座屈補剛材のクリアランスは板厚の実勢值やリ ングの製作誤差を考虑し， $1 ， 2 \mathrm{~mm}$ の 2 種類を用意した。なお， 試験体を載荷装圈に設置した状態でクリアランスを計測し，ク リアランスの設計値と実勢值の差が $10 \%$ 以下となっていること を確認している．座屈補剛材の板厚は塑性化スプライスの板厚

表 1 。低降伏点瞩の素材試験結果

\begin{tabular}{c|c|c|c|c}
\hline 鋼種 (板更) & $\begin{array}{c}\text { 降伏点 } \\
{\left[\mathrm{N} / \mathrm{mm}^{2}\right]}\end{array}$ & $\begin{array}{c}\text { 引張强さ } \\
{\left[\mathrm{N} / \mathrm{mm}^{2}\right]}\end{array}$ & $\begin{array}{c}\text { 降伏比 } \\
{[\%]}\end{array}$ & $\begin{array}{c}\text { 一様伸び } \\
{[\%]}\end{array}$ \\
\hline \hline LYP225 $(\mathrm{t}=12)$ & 218 & 288 & 76 & 32 \\
\hline
\end{tabular}

表 2。試験体一臨

\begin{tabular}{|c|c|c|c|}
\hline 試駼体名 & $\begin{array}{c}\text { 慗性化部艮さ } \\
l_{p}[\mathrm{~mm}]\end{array}$ & $\begin{array}{c}\text { クリアランス } \\
C \text { [mm] }\end{array}$ & $\begin{array}{c}\text { 補㣚材厚 } \\
t_{b}[\mathrm{~mm}]\end{array}$ \\
\hline S1. 6 & \multirow{6}{*}{$\begin{array}{c}90 \\
(\text { Sシリーズ) }\end{array}$} & \multirow{3}{*}{1} & 6 \\
\hline S1- 9 & & & 9 \\
\hline S1-12 & & & 12 \\
\hline S2- 6 & & \multirow{3}{*}{2} & 6 \\
\hline S2- 9 & & & 9 \\
\hline S2-12 & & & 12 \\
\hline L1- 6 & \multirow{6}{*}{$\begin{array}{c}180 \\
(\text { Lシリーズ })\end{array}$} & \multirow{3}{*}{1} & 6 \\
\hline L1- 9 & & & 9 \\
\hline $\mathrm{L} 1.12$ & & & 12 \\
\hline L2. 6 & & \multirow{3}{*}{2} & 6 \\
\hline L2. 9 & & & 9 \\
\hline L2-12 & & & 12 \\
\hline
\end{tabular}

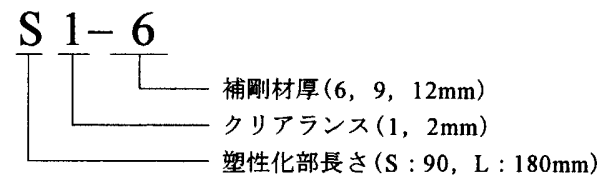

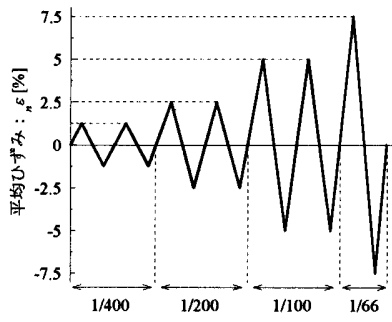

(a) S シリーズ

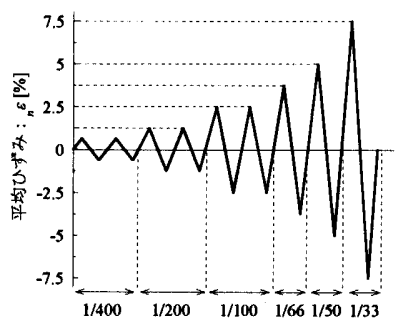

(b) L シリーズ
図 5, 載荷履歴 


$$
\mathrm{S} \text { シリーズ }
$$

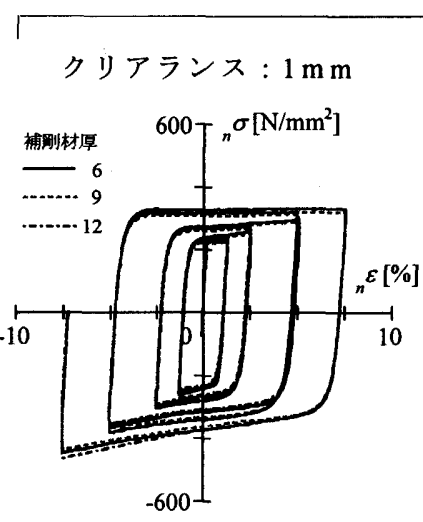

(a) S1-6, 9, 12
クリアランス : $2 \mathrm{~mm}$

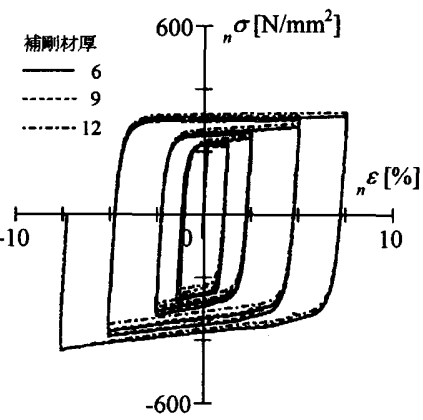

(b) S2-6, 9, 12
L シリーズ

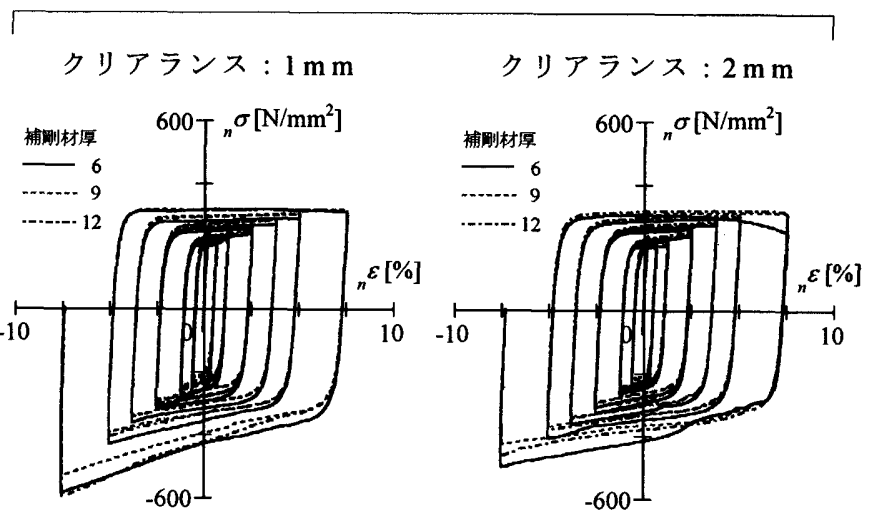

(c) L 1-6, 9, 12

(d) L 2-6, 9, 12

図 6. 梁下ダンパー要素の挙動 (公称応力 $\left({ }_{n} \sigma\right)$ 一平均ひずみ $\left({ }_{n} \varepsilon\right)$ 関係)

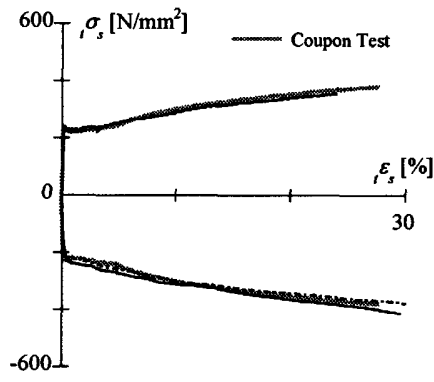

(a) S1-6, 9, 12

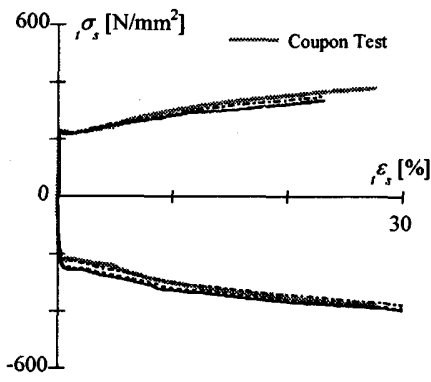

(b) $52-6,9,12$

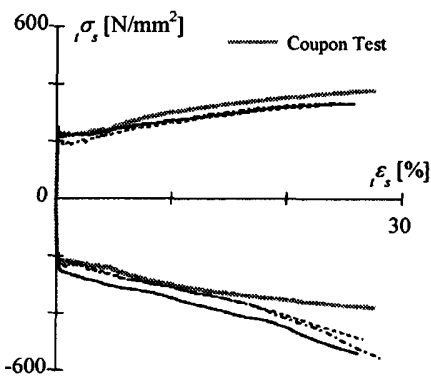

(c) $\mathrm{L} 1-6,9,12$

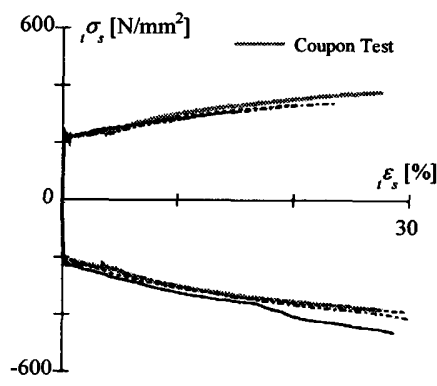

(d) L2-6, 9, 12

図 7. 骨格曲線と素材試験結果の比較 (真応力 $\left({ }_{\mathrm{t}} \sigma_{\mathrm{s}}\right)$ 一真ひずみ $\left({ }_{\mathrm{t}} \varepsilon_{\mathrm{s}}\right)$ 関係)

以下の $6,9 ， 12 \mathrm{~mm}(\mathrm{SS} 400)$ の 3 種類を用意し，本実験では 1 次締 め $(40 \mathrm{kN})$ 程度で高力ボルト (M16(F10T))により取り付けた，座屈 補剛材を取り付ける高力ボルトは面内方向への座屈補剛を兼站 るが，面内方向のクリアランスは塑性化部ーリング間 $(1.5 \mathrm{~mm})$ ， リングー高カボルト間（ $0.5 \mathrm{~mm})$ ，高カボルトーボルト孔間 $(1.0 \mathrm{~mm})$ の合計で最大 $3.0 \mathrm{~mm}$ となっている．また，塑性化部と座 屈補剛材の接触により生じる摩擦力を低減するため, 塑性化部 にはアンボンド材を塗布した。

\subsection{2. 載荷方法}

実験は試験体の一端を固定し、ロードセルを含む他端側に強 制変位を与えることで行った．栽荷は塑性化部の平均ひずみを 用いた変位制御とし，設計時に想定した梁継手の回転変形で $1 /$ $400 ， 1 / 200,1 / 100,1 / 66,1 / 50,1 / 33 \mathrm{rad}$. に相当するひずみを正負 交番で繰り返し与えた。 また，圧縮時の変形状態を確認するた め, 載荷はすべて引張側を正として開始し，最終目標変位に到 達した後に荷重を除荷して終了した。制御に用いた塑性化部の 平均ひずみは，図 2.に示す最内縁接合ボルト間の相対変位から 塑性化部以外の弾性変形（計算値）を减じ，塑性化部元長さで除 した值となっている. 図 5.に載荷履歴を示す.

\section{2. 実験結果と考察}

全試験体の履歴挙動を公称応カー平均ひずみ関係として図 6 . に示す．また，体積一定の仮定に基づいて真応カ一真ひずみ関 倸に置換し，新たな応カレベルでの履歴曲線をつなぎ合わせて
できる骨格曲線 12 ，13) を素材試験結果とともに図 7.に示す，図は 各シリーズをクリアランス別に示し，補剛材厚の違いを線種に よって表現している. 図6.の公称応力はロードセルの計測値を 塑性化部の原断面積で除した值であり，ひずみと同様に引張側 を正としている.

まず塑性化部が短い S シリーズの履歴挙動を見ると，クリアラ ンス・補剛材厚によらず安定した履歴挙動を示している。また, 抽出した骨格曲線も素材試験結果と良い対応を示していること から， S シリーズでは適切な座屈補剛を施せたと言える.

塑性化部が長い $\mathrm{L}$ シリーズでは，クリアランス $2 \mathrm{~mm}$, 補剛材 厚 9, $12 \mathrm{~mm}$ の場合は同様に安定した履歴挙動を示し, 骨格曲線 も素材試験結果と良い対応を示している，補剛材厚 $6 \mathrm{~mm}$ の場合 には引張 $7.5 \%$ 載荷時に劣化が生じ，その直後の圧縮載荷で急激 に耐力が上昇した．実験後のL2-6には幅方向の絞りが生じてい る部分で短い波長の面外座屈が見られ，局所的に発生した座屈 が座屈補剛材とひっかかることで変形が進行せず，みかけの塑 性化長さが短くなったために急激な耐力上昇が現れたと考えら れる.一方, クリアランス $1 \mathrm{~mm}$ の場合には, 補剛材厚によらず, 圧縮 $7.5 \%$ 載荷時に耐力が上昇し，骨格曲線においても圧縮側で 素材試験結果との対态が急変している. 実験後の L 1 シリーズを 見るといずれの試験体も塑性化部の断面が長さ方向に一様でな く，断面がもっとも大きい部分ではクリアランスで吸収できる 以上に板厚が増大していた。これは終局時に塑性化部が一様に 
変形しておらず, 塑性化部の一部が（座屈補剛材と載荷治具に） 両面接触していたことを表している．よって，両面接触した部 位ではほとんど変形が生じず，L2-6 と同様にみかけの塑性化長 さが短くなったために急激な耐力上昇が現れたと考えられる.

塑性化部が両面接触した原因としては大きな圧縮ひずみ載荷 の影響が挙げられるが，いずれも圧縮 $5.0 \%$ 載荷までは安定した 履歴挙動を示しており，急激な耐力上昇は圧縮 $7.5 \%$ 載荷の引張 ひずみ領域で生じていることから，塑性化部が一様に変形でき る限界まで引張ひずみが蓄積し，その直後に圧縮載荷を行った ことが影響していると考えられる。ここで引張側の骨格曲線に 着目すると, 引張 $7.5 \%$ 載荷時には素材試験結果における一様伸 びの $85 \sim 90 \%$ までひずみが進展しており, 塑性化部を一様に変 形させるための目安として引張側骨格曲線における進展ひずみ 量が一つの指標となることを示唆している．つまり，履歴曲線 より抽出した引張側骨格曲線が一様伸びに近づくほど塑性化部 は均一に変形し難くなり，特にクリアランスが小さい場合には 圧縮時に両面接触を生じるため, 圧縮力下での安定した履歴挙 動は得にくくなると言える。

\section{3. 座屈補剛の評価}

一方，実験後の座屈補剛材には残留变形が見られず，履歴挙 動における耐力上昇も終局時に塑性化部が一様に変形しなかっ たことが原因であると考えられるため，本実験では適切な座届 補剛を施せたと言える。ここでは塑性化部の座屈によって生じ る面外力と, 座屈補剛材の耐荷機構を仮定することで本実験で の座屈補剛条件を評価する。

\section{3. 1. 塑性化部における面外力の設定}

まず塑性化部の座屈によって生じる面外力を設定する ${ }^{14)}$ ，図 8 に示すように塑性化部に高次モードの座屈が発生した際，座屈 波形を振幅 $C / 2$, 波長 $2 L$ の $\sin$ 波にモデル化すると，最大の傾き $\theta_{\max }$ は以下のように表せる。

$$
\theta_{\max }=\frac{\pi C}{2 L} \quad\left(\because y^{\prime}=\frac{\pi C}{2 L} \cos \frac{\pi}{L} x\right)
$$

ここで塑性化部に作用する力と，この最大の傾き方向に作用す る力が等しいとすれば, 塑性化部の座屈によって生じる面外力 $F$ (1 波あたり) は, 塑性化部に作用する最大軸力 $P_{\text {max }}$ から以下の ように表せる。

$$
F=2 \cdot P_{\max } \cdot \theta_{\max }=\frac{\pi P_{\max } C}{L}
$$

ここで半波長 $L$ は塑性化部の板厚 $t_{p}$, 応力ーひずみ関倸における 最大応力 $\sigma_{\max }$, 接線係数 $E_{p}$ を用いて以下のように表す．なお，式 の誘導過程については附録 $\mathrm{A}$ を参照されたい.

$$
L^{2}=\frac{\left(\pi \cdot t_{p}\right)^{2} \cdot E_{p}}{24 \sigma_{\max }}
$$

\section{3. 2. 座屈補剛材の耐荷機樯}

面外力を座屈補剛材のボルトピッチ中央に作用させ, 高力ボ ルトでの境界条件をピンとしたときが最も過酷な条件となる ${ }^{15)}$. ここで座屈補剛材に作用する最大モーメント $M$ はボルトピッチ

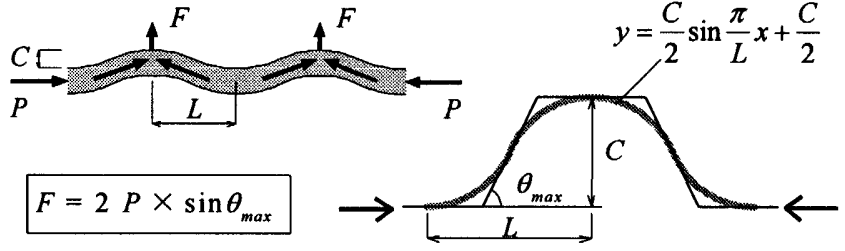

\begin{tabular}{|c|c|c|c|c|c|c|}
\hline 試堬体名 & $\begin{array}{l}\sigma_{\max } \\
{\left[\mathrm{N} / \mathrm{mm}^{2}\right]}\end{array}$ & $\begin{array}{l}\beta \\
{[\%]}\end{array}$ & $\begin{array}{c}L \\
{[\mathrm{~mm}]}\end{array}$ & $\begin{array}{c}F \\
{[\mathrm{kNN}]}\end{array}$ & $\begin{array}{c}M \\
{[\mathbf{k N}-\mathbf{m}]}\end{array}$ & $\begin{array}{c}\text { 㭪㓮条件 } \\
M / M_{y}\end{array}$ \\
\hline S1- 6 & -448 & 2.6 & 26 & 26 & 319 & 1.2 \\
\hline S1. 9 & -436 & 2.5 & 27 & 25 & 309 & 0.5 \\
\hline S1-12 & -466 & 2.7 & 26 & 27 & 333 & 0.3 \\
\hline \$2- 6 & -431 & 2.6 & 27 & 48 & 604 & 8 \\
\hline S2- 9 & -430 & 2.5 & 27 & 49 & 611 & 11 \\
\hline S2-12 & -433 & 2.4 & 26 & 50 & 624 & 0.6 \\
\hline L1- 6 & -586 & 2.5 & 27 & 24 & 305 & 12 \\
\hline L1- 9 & -531 & 2.3 & 28 & 18 & 228 & 0.4 \\
\hline L1-12 & -603 & 2.4 & 27 & 23 & 287 & 0.3 \\
\hline L2- 6 & -500 & 2.5 & 27 & 45 & 562 & (6) \\
\hline L2. 9 & .426 & 2.1 & 24 & 53 & 657 & 1.1 \\
\hline L2-12 & -465 & 2.2 & 24 & 58 & 727 & 0.7 \\
\hline
\end{tabular}

図 8．塑性化部の座屈によって生じる面外力

表 3。座屈補剛条件の計算結果

$l_{B}$ から以下のように表せる.

$$
M=\frac{F \cdot l_{B}}{4}
$$

この作用モーメントに対して座屈補剛材が降伏しないこと，つ まり座屈補剛材の降伏曲げモーメント $M_{y}$ を作用モーメント $M$ 以 上にすることを本実験での座屈補剛条件とした。

$$
\frac{M}{M_{y}} \leq 1
$$

$M_{y}=\frac{{ }_{b} b \cdot{ }_{b} t^{2} \cdot{ }_{b} \sigma_{y}}{6}$

ここで, ${ }_{b} b$ : 座屈補剛材の幅

${ }_{b} t:$ 座屈補剛材の板厚

${ }_{b} \sigma_{y}:$ 座屈補剛材の降伏点応力

\section{3. 3. 実験結果との比較}

座屈補剛条件の計算結果を表 3. にまとめる. 塑性化部に作用 する力 $P_{\text {max }}\left(\sigma_{\text {max }}\right)$ は実験で得られた最大軸力もしくは急激な耐力 上昇以前の載荷までの最大軸力とした。また接線係数は文献 15) と同样の手法により求め(附録 $\mathrm{B}$ に詳細を示す)，接線係数の初 期剛性に対する比 $\beta$ を表中に示した。計算結果では補剛材厚が 小さい,もしくはクリアランスが大きいS1-6, S2-9, L1-6, L2-9 では作用モーメントが補剛材の降伏モーメントを $10 \sim 20 \%$ ほど 上回っており, 補剛材厚・クリアランスともに不利な S2-6, L26 では作用モーメントが降伏モーメントの 2 〜 倍となり, 座屈 補剛条件を满足していない，寒験結果では座屈補剛条件が厳し いこの 2 体も安定した履歴挙動を示しており，座屈補剛条件は 安全側の評価となっている. また, 本実験結果だけで座屈補剛 条件が塑性変形能力に与える影響に言及するには至らないが, 最も座屈補剛条件が厳しいL2-6が唯一引張側で耐力低下を示し た試験体となっていることから，上述した座屈補剛条件を十分 に満足することが望ましいと言える。 


\section{3 、塑性化スプライスを設置した梁継手の実験}

\section{1. 实験計画}

次に梁継手に塑性化スプライスを設置した部材の力学挙動を 把握するため，梁の繰り返し曲げせん断実験を行った．実験方 法は図 9.に示す柱を治具としたト字形試験体による片持ち梁形 式とした，試験体のせん断スパンを $1375 \mathrm{~mm}$ とし，梁にはウェブ の幅厚比が大きいBH-450x130x6x9(SS400)，ブラケットには曲げ 降伏を回避するために梁幅を広くした BH-450x200x6x9（SS400）を 用いた。これらを標準断面として塑性化スプライスの塑性化部 長さを変えた S，Lシリーズ，継手近傍のディテールを変えた LB シリーズ，せん断スパン・梁せいを大きくした試験体 LR の計 4 シリーズを用意した。なお，試験体 LR は実大規模を想定してお り，S，L，LB シリーズは縮小試験体となっている. 塑性化スプ ライスには前章とほぼ同形状の塑性化部を設け， S, L シリーズ ではさらに塑性化部と座屈補剛材のクリアランスが $1,2 \mathrm{~mm}$ の ものを用意した，LB シリーズは弾性スプライスを 1 面摩擦とし てせん断伝達を緩和したもの，ブラケットウェブを $6 \mathrm{~m} \mathrm{~m}$ から

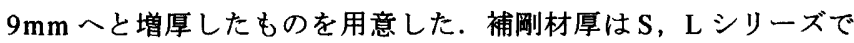
$6 \mathrm{~mm}$, LB シリーズで $9 \mathrm{~mm}$, 試験体 LR で $12 \mathrm{~mm}$ の鋼板（SS400）を それぞれ用いており，試験体 S2，L2 がもっとも笄しい座屈補剛 条件となっている。試験体一覧を表 4.に示し， $S$ シリーズ，試験 体 LB-S，試験体 LR の接合部詳細を図 10. に例示する. 塑性化ス プライスは前章と同一ロットの低降伏点鋼により製作し，その 他の使用鋼材についてはJIS-1A 号引張試験片による素材試験結 果を表 5.にまとめる。また，塑性化スプライス，弾性スプライ スの設計方針とその詳細については附録 C に示す.

載荷は柱両端をピン治具で支持し，梁の自由端に接続したオ イルジャッキにより強制変位を与えて行う。載荷履歴は梁変形 をせん断スパンで除した部材角で $\pm 1 / 400 ， \pm 1 / 200 ， \pm 1 / 100 ， \pm$ $1 / 50, \pm 1 / 33,+1 / 25 \mathrm{rad}$. とし, 試験体 LR のみ $\pm 1 / 100,+1 / 66,-1 /$ $30 \mathrm{rad}$. とした．図11.に載荷履歴を示す．ここで制御に用いた梁 変形とは梁先端変位から柱とパネルゾーンの変形成分を減じた 值であり，塑性化スプライスが引張となる時を正としている，な お，載荷時には図 9. 中の破線位置で梁に横補剛を施した。

\section{2. 実験結果と考察}

部材の挙動を各シリーズごとに図 12.に示す. S, L シリーズで はクリアランスの違いを線種によって表現している．図中縌軸

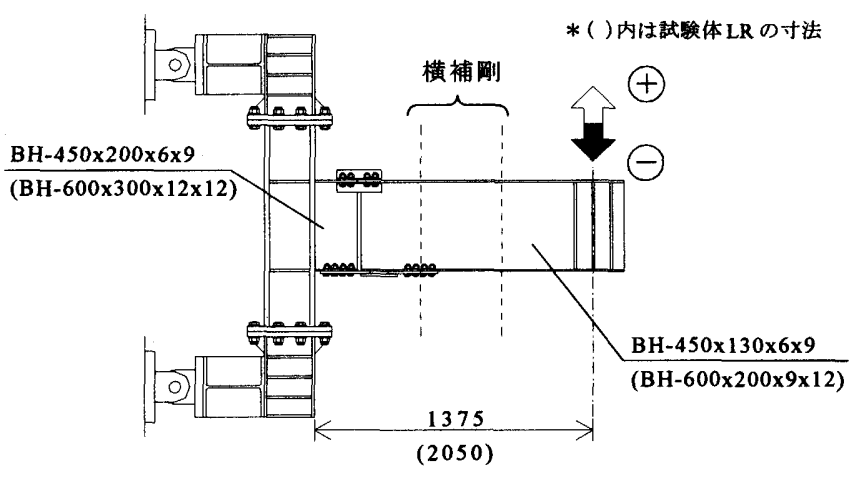

図 9. 載荷装置

表 4. 試験体一覧

\begin{tabular}{|c|c|c|c|c|c|}
\hline シリース & 試駼体名 & $\begin{array}{c}\text { 塑性化部長さ } \\
l_{p}[\mathrm{~mm}]\end{array}$ & $\begin{array}{c}\text { クリアランス } \\
C \text { [mm] }\end{array}$ & $\begin{array}{c}\text { 畨劓材厚 } \\
t_{b}[\mathrm{~mm}]\end{array}$ & 特部事碩 \\
\hline \multirow{2}{*}{$\mathbf{s}$} & s1 & \multirow{2}{*}{90} & 1 & \multirow{4}{*}{6} & \multirow{4}{*}{ - } \\
\hline & S2 & & 2 & & \\
\hline \multirow{2}{*}{$\mathbf{L}$} & LI & \multirow{4}{*}{180} & 1 & & \\
\hline & L2 & & \multirow{4}{*}{2} & & \\
\hline \multirow{2}{*}{ LB } & LB-S & & & \multirow{2}{*}{9} & 弾性スフラライスを1面摩攃 \\
\hline & LB-W & & & & ウェフ板厚 $(6 \rightarrow 9 \mathrm{~mm})$ \\
\hline LR & $\mathbf{L R}$ & 280 & & 12 & せん盺スパン・梁せいー(大) \\
\hline
\end{tabular}

表 5. 使用鋼材の素材試験結果

\begin{tabular}{c|c|c|c|c|c}
\hline \multirow{2}{*}{ 使用箇所 } & 銅種 (板厚) & $\begin{array}{c}\text { 降伏点 } \\
{\left[\mathrm{N} / \mathrm{mm}^{2}\right]}\end{array}$ & $\begin{array}{c}\text { 引張强さ } \\
{\left[\mathrm{N} / \mathrm{mm}^{2}\right]}\end{array}$ & $\begin{array}{c}\text { 降伏比 } \\
{[\%]}\end{array}$ & $\begin{array}{c}- \text { 様伸び } \\
{[\%]}\end{array}$ \\
\hline \multirow{4}{*}{ 梁・ブラケット }
\end{tabular}

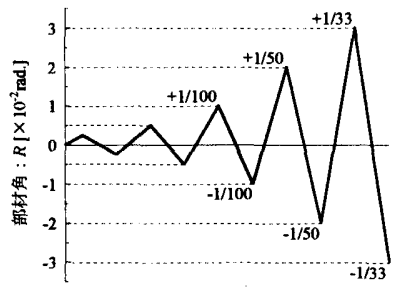

（a）標準載荷履歴

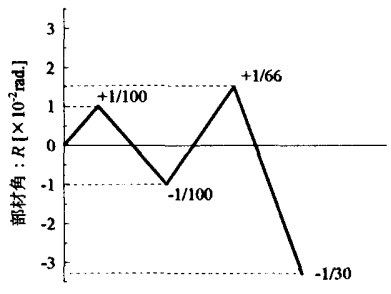

（b）試験体 LR
図 11 . 載荷履歴

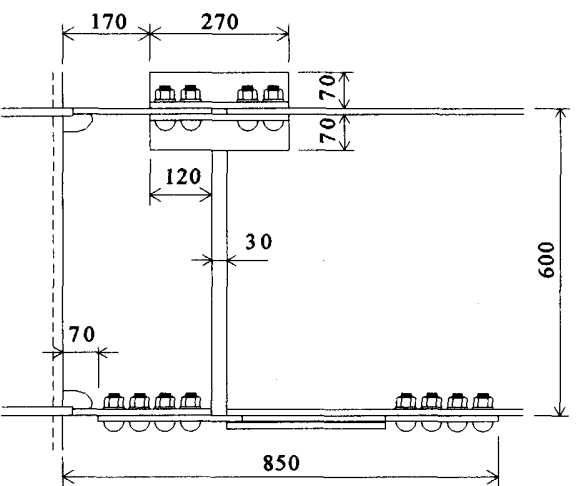

（c）LR（せん断スパン・梁せいい(大)）

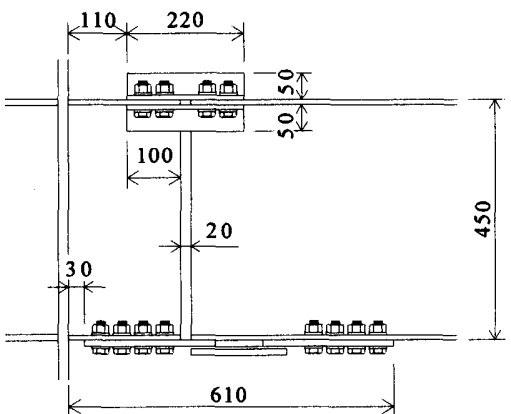

(a) S シリーズ（標準型）

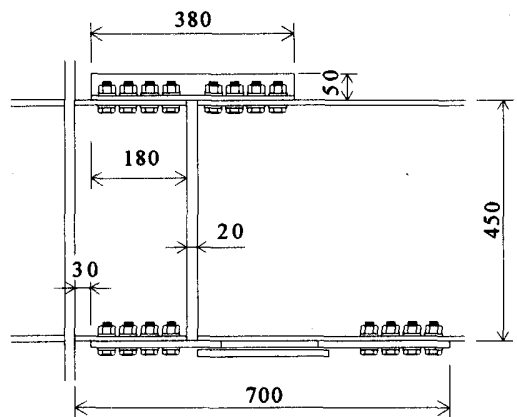

(b) LB-S（弾性スプライスを1 面摩擦）

図 10 . 接合部詳細 


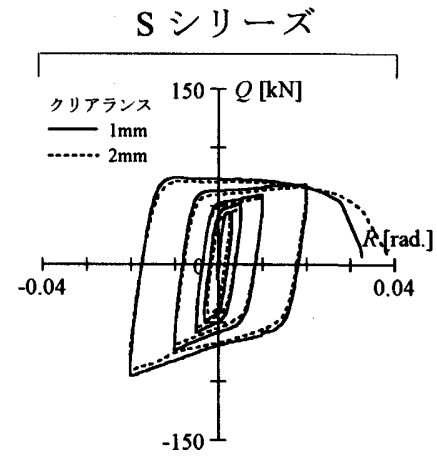

(a) S1, S2

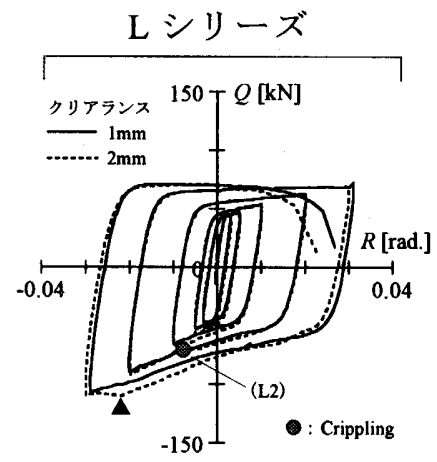

(b) $\mathrm{L} 1, \mathrm{~L} 2$

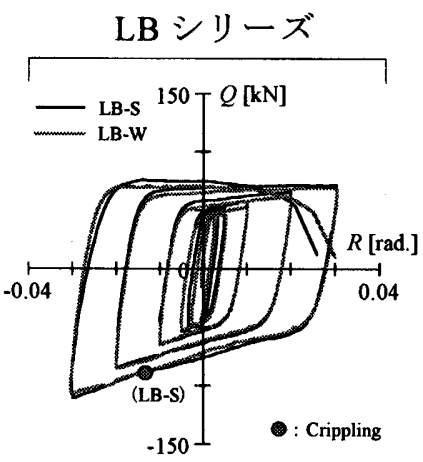

(c) LB-S, LB-W

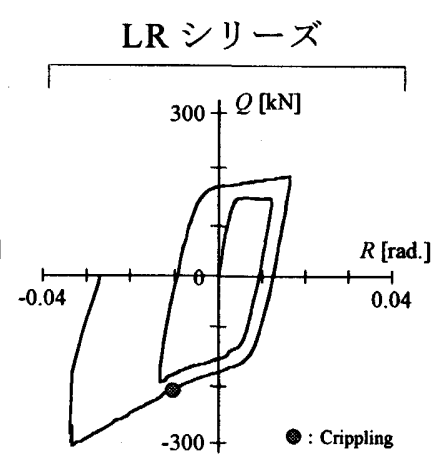

(d) LR

図 12. 部材としての挙動 (せん断力 $(\mathrm{Q})$ 一部材角 $(\mathrm{R})$ 関係)

のせん断力はオイルジャッキに取り付けたロードセルの計測値 であり，横軸の部材角は制御に用いた值である. 全試験体とも に負側耐力が正側耐力に比べて大きいが安定した履歴挙動を示 し, S シリーズでは+1/33rad. 載荷時に, L, LB シリーズでは+1/ $25 \mathrm{rad}$. 載荷時にそれぞれ塑性化部のほぼ中央位置で破断が生じて 急激に耐力を喪失した。履歴挙動より得られた初期剛性を，剛 接梁の初期剛性 (計算值) とともに表 6. に示す. 塑性化スプライ スを設置した梁継手はS，L，LB シリーズでは剛接合の $70 \sim 85 \%$ に初期剛性が低下しているが，実大規模の LR では剛接合と同程 度の初期剛性を有している。これは縮小試験体では力の伝達が 行われる摩擦接合部を試験体の縮尺に対して短くできなかった ことが影響していると考えられる.

塑性化部長さが同じ L シリーズと LB シリーズを比較すると， 大局的には両者の履歷挙動にほとんど差はないが，もっとも座 屈補剛条件が綮しいL2 では終局時 (-1/33rad. 載荷) にブラケット 側の塑性化部端部で面外座屈が生じ, 座屈補剛材が大きく変形 して耐力低下（図 12.(b)のム) を示している，実験時には後述する ウェブクリップリングやせん断伝達に伴う梁上フランジの面外 変形16)によって梁とブラケットとの間に大きな鉛直ずれが見ら れ，これが前章の実験では生じなかった塑性化部端部での面外 座屈を引き起こしたと考えられる。したがって，終局時まで塑 性化スプライスを安定的に機能させるためには, 前章の座屈補 剛条件を十分に満足させるとともに, ブラケット部や弾性スプ ライスでのせん断伝達に留意して設計する必要がある.

3. 3. ウェブクリップリング

$\mathrm{S}$ シリーズとブラケットウェブを増厚した LB-W を除く全試験 体では，弹性スプライス直下でブラケットウェブが面外へはら み出す, いわゆるウェブクリップリング ( 以後, 単にクリップリ ング）の発生が見られた。降伏後の塑性化スプライスにはせん断 力の伝達がほとんど期待できず，梁からのせん断力は弾性スプ ライスを介してブラケットに伝達されるため, このせん断力が クリップリングを引き起こしたと考えられる，L2，LB シリーズ， LRには梁とブラケットの表裹にひずみゲージを貼付し，ひずみ の計測值が分岐する時点をクリップリングの発生として履歴举 動に○印で示した。ひずみダージの貼付位置とクリップリング の定義を図 13.に示す，標準断面を有する L2 では $72 \mathrm{kN}$ ，弾性ス プライスを 1 面摩擦とした LB-S では $89 \mathrm{kN}$ でそれぞれクリップリ
表 6. 初期剛性の実験值

\begin{tabular}{|c|c|c|c|}
\hline 試験体名 & $\begin{array}{c}\text { 実験值 } \\
{\left[\times 10^{3} \mathrm{kN} / \mathrm{m}\right]}\end{array}$ & $\begin{array}{c}\text { 制接合 } \\
\text { (計算值) } \\
{\left[\times 10^{3} \mathrm{kN} / \mathrm{m}\right]}\end{array}$ & $\begin{array}{c}\text { 実験值 / 制接合 } \\
{[\%]}\end{array}$ \\
\hline S1 & 25 & \multirow{6}{*}{29} & 86 \\
\hline S2 & 25 & & 86 \\
\hline L1 & 22 & & 76 \\
\hline L2 & 21 & & 72 \\
\hline LB-S & 21 & & 72 \\
\hline LB-W & 21 & & 72 \\
\hline LR & 34 & 33 & 103 \\
\hline
\end{tabular}

ングが発生しており，ブラケットウェブを $9 \mathrm{~mm}$ に增厚した LB$\mathrm{W}$ ではクリップリングが発生していない.これらの結果は弾性 スプライスからブラケットへのせん断伝達の緩和, ブラケット ウェブの增厚がブラケットにおけるクリップリング耐カの上昇 に寄与することを表している。

また，いずれの試験体も梁側ではクリップリングの発生は確 認されなかった. 梁ウェブの幅厚比を大きくして行った塑性化 スプリットティの実験 ${ }^{11)}$ １6)においてもクリップリングの発生は 確認されておらず，また既往のクリップリング耐力式例えは17) は荷 重点から反力点までの距離が長いとクリップリング耐力が上昇 することを表している. したがって，クリップリングはブラケッ トのようにみかけの短スパン部分に集中圧縮力が作用する場合 に発生し易く，継手部分に梁下ダンパーを設置した本構造シス テムではクリップリング耐力の検討が必要となる.

\section{4. クリップリング耐カの評価}

一方，いずれの履歷挙動にもクリップリング発生の影響はほ とんど現れていないが，これは梁に十分な横補剛を施して実験 を行ったためであり，実際にはクリップリングの発生により部 材は不安定になりやすくなると考えられる。また，座屈補剛条 件の厳しいL2 ではクリップリングの発生が梁上フランジの面外 変形とともに梁の鉛直ずれを生じさせ，塑性化部端部での面外 座屈を誘発したと考えられることから，早期のクリップリング の発生は回避する必要がある。クリップリングについては

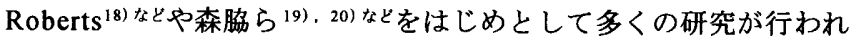
ているが，ここでは指針や規準で提示されているクリップリン グ耐力式 17)，21) 23) を用いて実験結果の評価を試みる. 


\subsection{1. 既往の耐力式}

日本建筑学会の限界状態設計指針 ${ }^{17)}$ では AISC LRFD Spec. (1986) 21) を参考にクリップリング耐力式を提示しているが，載荷幅の影 響が考慮されていない，本実験ではせん断伝達の緩和がクリッ プリング耐カの上昇に寄与していたことから，載荷幅の影響が 考虑されている耐力式のみを用いることとした。 まず, AISC Spec. （DRAFT, 2004） ${ }^{22)}$ では荷重点から反力点までの距離が $d / 2$ より小さ い場合に,

$N / d \leq 0.2$ のとき

$$
R_{1}=0.40 t_{w}{ }^{2}\left[1+3\left(\frac{N}{d}\right)\left(\frac{t_{w}}{t_{f}}\right)^{1.5}\right] \sqrt{\frac{E F_{y w} \cdot t_{f}}{t_{w}}} \quad \cdots(7.1)
$$

$N / d>0.2$ のとき

$$
R_{1}=0.40 t_{w}^{2}\left[1+\left(\frac{4 N}{d}-0.2\right)\left(\frac{t_{w}}{t_{f}}\right)^{1.5}\right] \sqrt{\frac{E F_{y w} \cdot t_{f}}{t_{w}}} \quad \cdots(7.2)
$$

としてクリップリング耐カ式を与えている（AISC 式）。また AISI LRFD Spec. ${ }^{23)}$ では片持ち梁の先端に荷重点があり, 荷重点から反 力点までの距離が $1.5 h$ より小さい場合に，

$$
R_{2}=t_{w}{ }^{2} k C_{3} C_{4} C_{\theta}\left\{244-0.57\left(\frac{h}{t_{w}}\right)\right\}\left\{1+0.01\left(\frac{N}{t_{w}}\right)\right\} \quad \cdots(8)
$$

としてクリップリング耐力式を与えている(AISI 式). (7) 式, (8) 式 で用いる記号を図 14 .にまとめる。

\section{4.2. 実験結果との比較}

クリップリング耐力の計算值と実験値の比較を図 15. に示す. AISC 式では片持ち梁先端での荷重を評価するために, 載荷幅を $2 \mathrm{~N}$ とし，さらに(7) 式を1/2 倍したものを図中に示している，対
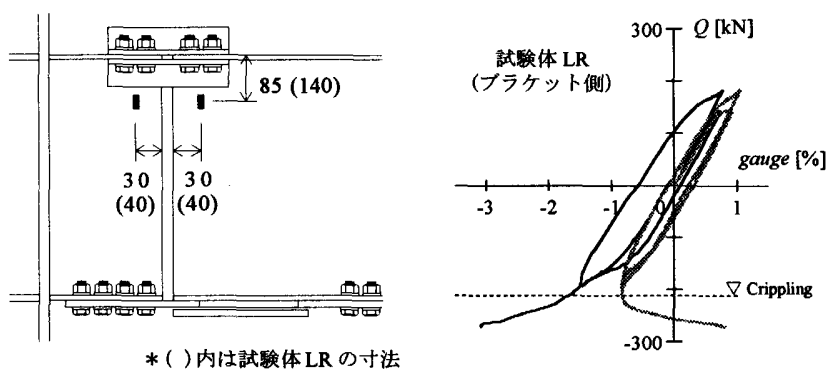

図 13.ゲージ貼付位置・クリップリングの定義

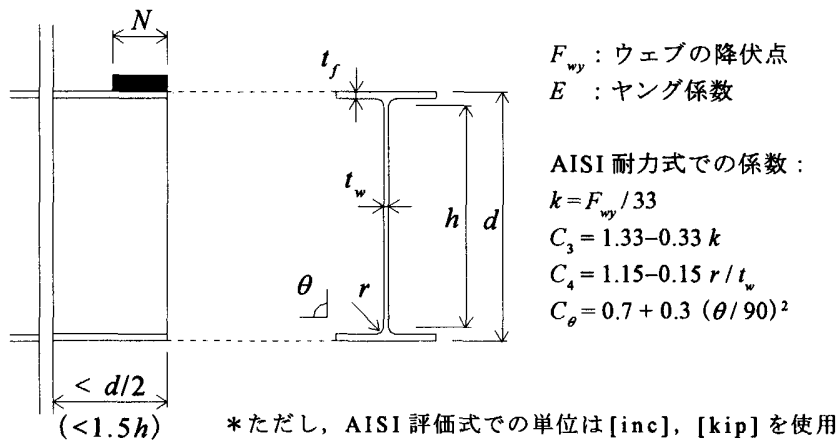

図14.クリップリング耐カ式での記号
称荷重を想定しているAISC 式を用いた計算結果は実験値との対 忘が悪く,クリップリング耐力の大きい試験体ほど実験結果を 過大評価している，一方，片持ち梁先端での荷重を想定してい るAISI 式を用いた場合には, クリップリングの発生が確認され たすべての試験体を安全側に評価できている.

なお，ここでは梁のせん断カが均一に弾性スプライスからブ ラケットへと伝達するものとしてクリップリング耐カを評価し た。しかしながら，弾性スプライスに生じる二次曲げモーメン トを図 16.のように仮定すると, 局所的には梁のせん断力 $Q$ より も大きな力 $Q$ 'が作用することになるため, クリップリング耐力 の評価には未だ検討の余地が残されている．また，局所的な力 $Q^{\prime}$ をできるだけ小さくするためには弾性スプライスの接合部分 を長くすることが効果的であるため, 弾性スプライスのディ テールについても改善の必要があり，せん断力に対する設計方 法の確立は今後の研究課題であると考えている.

\section{4. 結}

角形鋼管柱に通しダイアフラム形式で梁を溶接接合した一般 的な柱梁接合部においても梁下ダンパー列え゙10)なをを適用可能とす るため，梁継手の下フランジに塑性化スプライスを設置する構 造システムを提案した．本研究ではまず塑性化部におけるクリ アランスの確保方法を新たに提示し，座屈補剛条件に着目した 塑性化スプライス要素の軸方向載荷実験を行った，次いで，塑 性化スプライスを設直した梁継手の力学挙動を把握するため, 梁の繰り返し曲げせん断実験を行った, 以下に得られた結果・知 見をまとめる。

（1）塑性化スプライス要素の実験では，いずれの試験体も塑性 化部長さ・クリアランス・補剛材厚の座屈補剛条件によらず安

\begin{tabular}{|c|c|c|c|}
\hline \multirow{2}{*}{ 試糇体名 } & \multirow{2}{*}{$\frac{Q_{w c}[\mathrm{kN}]}{\text { 実験值 }}$} & \multicolumn{2}{|c|}{$R[\mathrm{kN}]$} \\
\hline & & AISC & AISI Spec. \\
\hline L2 & 72 & 122 & 66 \\
\hline LB-S & 89 & 173 & 74 \\
\hline LB-W & 108 & 311 & 150 \\
\hline LR & 210 & 317 & 172 \\
\hline \multicolumn{4}{|c|}{ 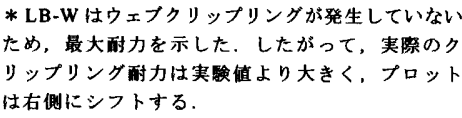 } \\
\hline
\end{tabular}
定した履歴挙動を示した。

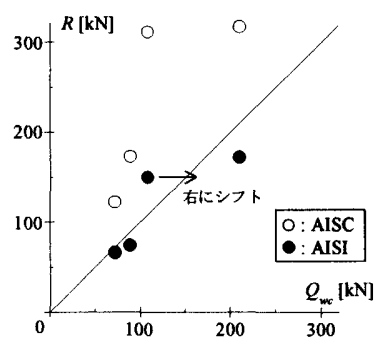

図 15. 計算值 $(R)$ と実験值 $\left(Q_{w c}\right)$ の比較

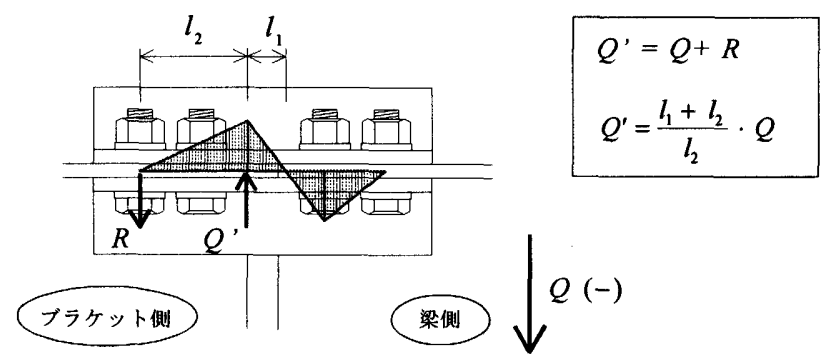

図 16. 弾性スプライスの二次曲げ（負側せん断作用時） 
（2）塑性化部が長く，クリアランスの小さい試験体では終局時 の圧縮載荷で急激に耐力が上昇したが，これは塑性化部が一様 に変形せず, 塑性化部の一部が両面接触してみかけの塑性化長 さが短くなったためである。これらの試験体では引張側の骨格 曲線が一様伸びの $85 \sim 90 \%$ まで進展した後に急激な耐力上昇 が現れているため，引張側骨格曲線での進展ひずみ量が安定し た履歴挙動を得るための一つの指標となると考えられる.

（3）塑性化部での座屈波形をモデル化して面外力を設定すると ともに，面外力に対する座屈補剛材の耐荷機構を想定すること で，本実験での座屈補剛条件を安全側に評価できた．

（4）塑性化スプライスを設置した梁継手の載荷実験では，負側 耐力が正側耐力に比べて若干大きいが，塑性化部長さ・クリア ランスによらず安定した履歴挙動を示した．また，剛接合の計 算値に対して縮小試験体の初期剛性は20〜30\%低下したが，ほ ほ実大の試験体では同程度の初期剛性を有する結果を得た。

（5）梁からのせん断力は弾性スプライスを介してブラケットに 伝達されるため，見かけの短スパン部分となるブラケット部分 では弾性スプライス直下でウェブクリップリングが発生し易い ことが分かった

（6）継手近傍のディテールを改善した実験結果から弾性スプラ イスからブラケットへのせん断伝達の緩和, ブラケットウェブ の增厚がクリップリング耐力の上昇に寄与することが分かっ た.また，これらの影響が考虑されている既往のクリップリン グ耐力式 22)，23)を用いて実験結果を概ね評価することができた。

なお，本文中で示したように弾性スプライス近傍でのせん断伝 達機棈を考えると，ブラケットには梁のせん断力よりも大きな 力が局所的に作用することになる。したがって，せん断伝達機 構の解明や弾性スプラィスのディテールの改善など, せん断力 に対する設計方法の確立が今後の研究課題であると考えている.

\section{【镢辞】}

本研究での実験の遂行にあたっては東京工業大学大学院生鄭景洙氏お よび元大学院生 小林和子孃，泳谷麻理缞の協力を得ました。本研究をま とめる際には建築学専攻竹内徹助教授にご助言をいただきました。また， 本論文の第一著者は日本学術振興会の特別研究員であり、科学研究費補助 金による助成を受けています。ここに記して感謝の意を表します。

\section{【考支献】}

1）和田章，岩田衛，清水敬三，安部重孝，川合廣樹：建築物の損傷制御設 計, 丸善, 1998

2）吹田啓一郎, 井上一朗, 竹内一郎, 宇野暢芳：座屈拘束された方杖ダン パーによる柱梁高力ボルト接合構造の力学挙動, 日本建築学会構造系論 文集, 第 571 号, pp.153-160, 2003.9.

3）會澤貴浩，山田哲，岩田衛：サステナブルビル構造システムの提案とそ の基本特性，日本建築学会環境系論文集，第581号，pp.109-116，2004.7

4) 張シシュン, 吹田啓一郎, 井上一朗, 竹内一郎, 宇野暢芳: H 形錳柱弱 軸方向と梁の高力ボルト接合に関する研究, 日本建築学会大会学術講演 梗概集 (北陸)，pp.637-638，2002.8.

5）聲高裕治，吹田啓一郎，張シシュン，安藤正和，宇野暢芳：H 形鋼柱弱 軸方向と梁の高力ボルト接合に関する研究，鋼構造年次論文報告集，第 11 巻, pp.641-648, 2003.11.

6）吉岡智和, 大久保全陸：梁端下端フランジに高力ボルト摩擦ダンパーを 設置した H 形銅梁の曲げせん断実験，日本建築学会構造系論文集，第 573 号, pp.177-184, 2003.11.

7）岩崎晃久，竹内一郎，井上一朗，吹田啓一郎，韾高裕治，宇野暢芳：工 ネルギー吸収要素を組み込んだ H 形鎆柱梁接合部に関する研究, 日本建 築学会大会学術講演梗概集 (北陸)，pp.639-640，2002.8.

8）甲津功夫, 木時亮, 水谷聡志, 吹田啓一郎：鉛ダンパー組込み梁継手を 有する䤡構造架構の動的応答性状に関する実験的研究, 日本建築学会構
造系詥文集，第 584 号，pp.161-167，2004.10

9）松尾真太朗, 馨高裕治, 井上一朗：座屈拘束型ダンパーを下フランジ側 に設置した梁の弾塑性挙動, 鋼構造年次論文報告集, 第 12 巻, pp.231-238, 2004.11.

10) 吉敷样一, 山田哲, 竹内徹, 鈴木一弁, 岡田健, 和田章: 損傷を梁端下 フランジの接合要素に限定する新しい鎆棈造骨組 その 1 ウェブ塑性化 スプリットティを用いた柱梁接合部の実験, 日本建築学会構造系論文集, 第 575 号, pp.131-120, 2004.1.

11）吉数样一，山田哲，竹内徽，鈴木一弁，佐伯英一郎，和田章：損傷を梁 端下フランジの接合要素に限定する新しい鋼構造骨組その2 床スラブ 付き架棈の実験，日本建築学会構造系諭文集，第 585 号, pp.177-184, 2004.1.

12）加藤勉，秋山宏，山内泰之：銅材の忘力ーひずみ履歴曲線に関する実験 則, 日本建築学会大会学術粨演梗概集, pp.937-938, 1973.10.

13）山田哲, 吉敷祥一：バウシンガー効果を考慮したダンパー用鋼材の简㳊 な履歴モデル，日本建築学会構造系踰文集，第 581 号, pp.109-116，2004.7.

14）下川弘海，棵野捷輔，神谷誠，伊藤茂樹，川口淳, 加村久哉, 廣田実 : 角形銅管で補㣚された平鋼ブレースの弾望性性状に関する研究（その7）。 日本建築学会大会学術譜演梗概集 (九州)，pp.843-844，1998.9.

15）百野泰樹，高裕治，井上一朗，諸岡繁洋：方杖ダンパーの座屈拘束設 計と性能確認実験，銅構造論文集，第 12 巻第 45 号, pp.233-241、2005.3.

16）山田哲, 吉数祥一, 竹内徹, 鈴木一弁, 佐伯英一郎, 和田章: 然性化不 プリットティを用いたドライフレームに関する研究(その12，13 せん断 伝達機構の実験)，日本建筑学会大会学術講演梗概集（北海道），pp.609$612,2004.8$.

17）日本建策学会：鋼構造限界状您設計指針・同解説，1998，10

18) Roberts, T.M. and Chong, C.K. : Collapse of Plate Girders under Edge Loading, Proc. of ASCE, Vol.107, ST8, pp.1503-1509, 1981.8.

19）森䏦良一，渑本哲四郎，三村裕一：局所荷重を受ける析の耐荷力，士木 学会铪文報告集, 第 339 号, pp.69-77, 1983.11.

20）森脇良一，滝本哲四郎，安井義則：局所荷重を受ける桁の耐荷力算定法 の抬張，士木学会铪文報告集，第 392 号 / I -9,pp.281-287，1988.4.

21) AISC : Manual of Steel Construction - Load \& Resistance Factor Design, First Edition, 1986.

22) AISC : Specification for Structural Steel Buildings, 2005.3.

23) AISI : Load \& Resistance Factor Design( LRFD) Specification for Cold-Formed Steel Structural Members, 1991

24）日本建築学会：銿橉造接合部設計指針，2001

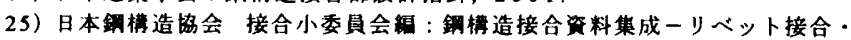
高力ボルト接合一，技報堂出版，1977.3。

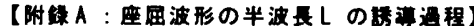

本文中の（3）式で表される塑性化スプライスの塑性化部における座屈波形 の半波長 $L$ の誘導過程について示す.

望性化スプライスが降伏軸力に達すると本文中の図 8.で示したような振幅 $C / 2$, 波長 $2 L$ の sin 波で表される面外座屈を生じ, この座届波形がひずみ硬化 による耐力上昇や練り返し荷重に対しても変わらないと仮定する。ここで塑 性化部の断面に軸力 $P$ を原断面䅡で除した平均軸応力 $\sigma$ 。，偏心曲げによる 曲率が生じるとすれば, 図心からh離れた位圈での応力 $\sigma$ は次式で表せる. なお，塑性域での接線倸数 $E$, は一定であると考える.

$$
\sigma=\sigma_{0}+\phi \cdot h \cdot E_{p}
$$

この断面における曲げモーメントは $M=\int \sigma \cdot h \cdot b d h$ で表せる.

$$
M=\phi \cdot E_{p} \cdot \int h^{2} d A=E_{p} I \cdot \phi
$$

曲率は座屈波形を二階微分したものであり，曲率と曲げモーメントの正負 を考えれば，曲げモーメントM と座屈波形yの関係は次式で表せる。

$$
M=E_{p} I \frac{d^{2} y}{d x^{2}}
$$

外力としての曲げモーメントは $M=P \cdot y($ 引張が正) として表せ, 座屈波形に おいて $(\pi / L) x=1$ となる点を考えると，

$$
P \cdot C=E_{p} I \frac{C}{2} \frac{\pi^{2}}{L^{2}}
$$

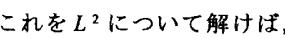

$$
L^{2}=E_{p} I \frac{\pi^{2}}{2 P}
$$

塑性化部の断面（板厚 $t_{p}$, 幅 $b$ ）を代入して整理すれば，次式が得られる.

$$
L^{2}=E_{p} \cdot \frac{b \cdot t_{p}{ }^{3}}{12} \cdot \frac{\pi^{2}}{2 \cdot\left(b \cdot t_{p} \cdot \sigma_{0}\right)}=\frac{\left(t_{p} \cdot \pi\right)^{2} \cdot E_{p}}{24 \sigma_{0}}
$$

塑性化スプライスが十分に塑性化した状態を考え, 上式の平均軸応力 $\sigma_{0}$ を $\sigma_{\max }$ に置き換えれば，本文中の（3）式が得られる. 
【附録 $B$ ：接線保数 $E$ 。の算出方法】

本文中で用いた接線保数 $E_{p}$ は任意の絽り返し荷重を受ける場合の応力上年 を考虑して定義する必要があるが,このような接線倸数を理論的に求めるこ とはできない，したがって，本研究では文献 15）と同様の手法を用い，接線 保数を実験より得られた応力ーひずみ関係から求めた。 すなわち，塑性化ス プライスの応カーひずみ関係において载荷ループごとに得られる圧縮側の最 大忘力点を抽出し，各点をつなぎ合わせてできる曲線の二次剛性としている. 接線係数の求め方を附録図 $\mathrm{B}$ に例示する.

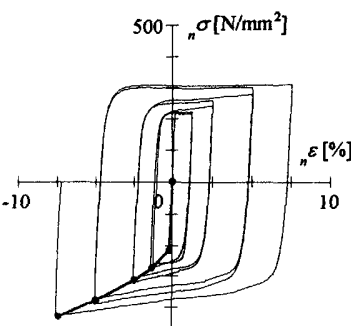

$-5001$

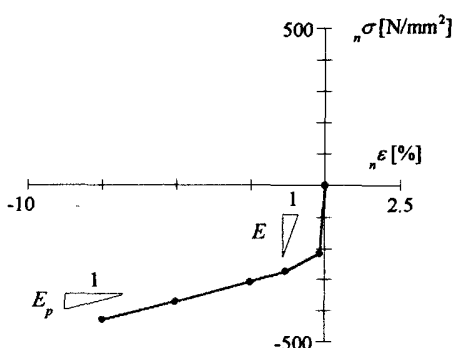

$-500+$
附録図 $\mathrm{B}$. 接線係数 $E_{p}$ の求め方

\section{【附録 C：部材实験における接合部の設㖕方針】}

本文 3 章の部材実験における接合部（塑性化スプライス，弾性スプライス） の設計方針とその詳細について示す.

塑性化スプライスはひずみ硬化によって耐力が上昇しても梁フランジに損 傷が及ばないよう，使用鋼材の規格耐力から求められる塑性化スプライスの 最大耐力が梁フランジの降伏耐力を下回るように断面積を決定している．梁 フランジの原断面積に対する塑性化部の断面積は，S，L，LB シリーズでは 40\%, LR では 55\% 程度となっている. また, 塑性化部の長さについては, 梁 継手の回転変形で $1 / 100 \mathrm{rad}$. に相当する軸変形に対して塑性化部のひずみが $\mathrm{S}$ シリーズでは $5.0 \%, L ， L B$ シリーズでは $2.5 \%$, LR では $2.0 \%$ 程度となるよう に決定している，附録図 C-1，に塑性化スプライスの詳細を示す.
一方, 弾性スプライスには塑性化スプライスの最大耐力と同等の軸力が作 用するとともに，梁からの全せん断力が作用すると考えられる. 本実験では これらの外力を別々に考え，いずれの外力に対しても弾性スプライスの降伏 軸力, 降伏せん断耐力が上回るように設計した. 本文中でも述べたようにせ ん断力に対する設計方法の確立は今後の検討課題であるが，実験を行うに当 たっては既往の研究5，24，25) なとを参考に本文中の図 16. に示す二次曲げモー メントを仮定して降伏せん断耐力を算出した. すなわち, 降伏せん断耐力は 二次曲げモーメントの両端が補剛リブの全塑性モーメントに達したときのせ ん断力とした. なお, 弾性スプライスが二面摩擦の場合には梁フランジ上下 面それぞれの降伏せん断耐力の和を用いている，附録図 C-2.に弾性スプ ライスの詳細を示す.

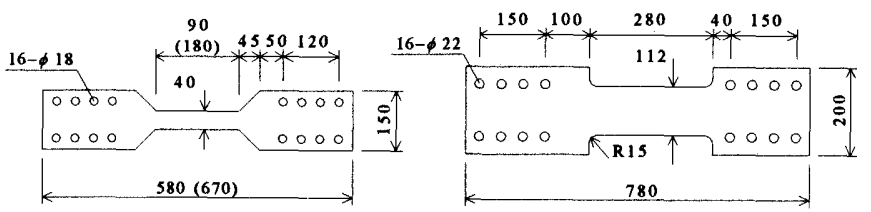

(a) S, L, LB シリーズ

(b) LR

附録図 C-1．塑性化スプライスの詳細

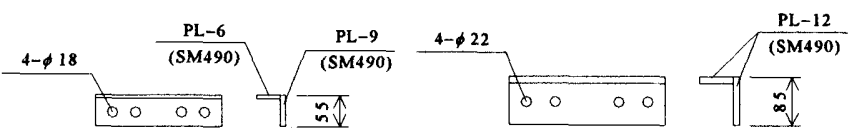

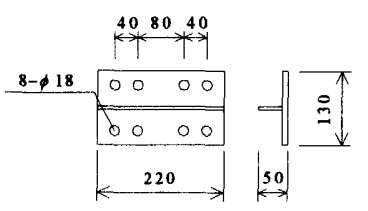

(a) S，L，LB シリーズ

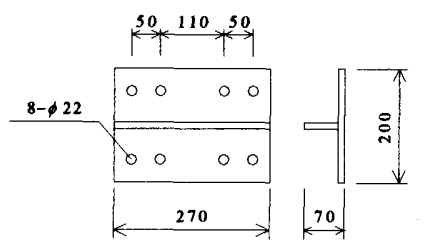

(b) LR
附録図 C-2。弾性スプライスの詳細 